\title{
Melanotic medullary carcinoma of thyroid - report of a rare case with brief review of literature
} Kamaljeet Singh ${ }^{1}$, Mehar C Sharma*1, Deepali Jain ${ }^{1}$ and Rajinder Kumar ${ }^{2}$

Address: ${ }^{1}$ Department of Pathology, All India Institute of Medical Sciences, New Delhi, India and ${ }^{2}$ Department of Surgery, All India Institute of Medical Sciences, New Delhi, India

Email: Kamaljeet Singh - kjsingh@yahoo.co.in; Mehar C Sharma* - sharmamehar@yahoo.co.in; Deepali Jain - deepalijain76@gmail.com; Rajinder Kumar - rajinderk@yahoo.com

* Corresponding author

Published: II January 2008

Diagnostic Pathology 2008, 3:2 doi:10.1186/1746-1596-3-2
Received: 23 August 2007

Accepted: II January 2008

This article is available from: http://www.diagnosticpathology.org/content/3/1/2

(C) 2008 Singh et al; licensee BioMed Central Ltd.

This is an Open Access article distributed under the terms of the Creative Commons Attribution License (http://creativecommons.org/licenses/by/2.0), which permits unrestricted use, distribution, and reproduction in any medium, provided the original work is properly cited.

\begin{abstract}
Background: Melanin production in medullary carcinoma is extremely uncommon.

Case presentation: We report a rare variant of medullary carcinoma of thyroid with melanin production in a 52-year-old woman who presented with swelling in the thyroid of 3 months duration. This tumor recurred thrice in two years after surgery and patient died with metastasis. Microscopic examination showed typical morphology of medullary carcinoma with numerous cells loaded with melanin pigment as confirmed by bleached Fontana-Masson, negative iron and immunohistochemical stains. Tumor cells were diffusely immunopositive for calcitonin, HMB-45, chromogranin, synaptophysin, CEA but showed focal paranuclear dot positivity for cytokeratin. No $\mathrm{C}$-cell hyperplasia was seen in the adjacent thyroid gland. Nature of the pigment was further confirmed on ultra structural examination.

Conclusion: Melanotic medullary carcinoma is an extremely uncommon entity. There is a need to report more number of cases in the literature for exact categorization and prognostication of this subtype of medullary carcinoma.
\end{abstract}

\section{Background}

Hazard et al segregated medullary carcinoma of thyroid (MTC) as a distinct entity in 1959 [1]. Calcitonin production by tumor cells is distinct and proves its origin from Ccells [2]. Medullary carcinoma cells have a confirmed ability to have a multi directional differentiation. Tumor cells are known to produce array of hormonal and non-hormonal products including mucin, peptides and amines [2]. Melanin production in medullary carcinoma is extremely uncommon and to the best of our knowledge only nine such cases have been reported in the literature [3-11] (Table 1). Melanocytic differentiation with melanin pro- duction is very rare, thus needs to be documented in order to know the exact behavior of this variant.

\section{Case presentation}

A 52-year-old female presented with swelling in the neck, in the thyroid region, of 3 months duration. She complained of difficulty in swallowing and pain in the swelling for the last fifteen days. Clinically, she was euthyroid and there was no past history of exposure to radiation. Routine blood examination and serum chemistry revealed no abnormalities. Serum T3, T4 and TSH levels were normal. Renal function and liver function tests were normal. 
Table I: Summary of published cases of melanotic medullary carcinoma thyroid

\begin{tabular}{|c|c|c|c|c|c|c|c|}
\hline \multirow{2}{*}{$\begin{array}{l}\text { S. No. } \\
\text { I. }\end{array}$} & \multirow{2}{*}{$\begin{array}{l}\text { Author \& Year } \\
\text { Marcus JN I982 [3] }\end{array}$} & \multirow{2}{*}{$\begin{array}{l}\text { Age } \\
\& \text { Sex } \\
53 / M\end{array}$} & \multirow{2}{*}{\begin{tabular}{|l|}
$\begin{array}{l}\text { Duration of } \\
\text { symptoms }\end{array}$ \\
15 days
\end{tabular}} & \multicolumn{2}{|c|}{ Histology } & \multirow{2}{*}{$\begin{array}{l}\text { Pigmentation } \\
\text { Dendritic cells }\end{array}$} & \multirow{2}{*}{$\begin{array}{l}\text { Follow up } \\
\begin{array}{l}\text { No evidence of recurrence or } \\
\text { metastasis } 2.5 \text { years after surgery }\end{array}\end{array}$} \\
\hline & & & & Classic & Dendritic cells & & \\
\hline 2. & Posen JA I984 [4] & $38 / F$ & 5 years & Classic & -- & Diffuse & Not mentioned \\
\hline 3. & Eng HL 1989 [5] & $68 / F$ & I month & Classic & Dendritic cells & Dendritic cells & Not mentioned \\
\hline 4. & Kimura N 1989 [6] & $62 / M$ & 2 years & Classic & Glandular & $\begin{array}{l}\text { Both } \\
\text { components }\end{array}$ & 2 years metastasis \\
\hline \multirow[t]{2}{*}{5.} & Beerman H 1990 [7] & $48 / F$ & I5 days & Classic & Spindle cells & Spindle cells & I3 months died with metastasis \\
\hline & & $36 / F$ & 14 years & Classic & -- & Diffuse & 20 months \\
\hline 6. & Romdhane KP I995 [8] & $51 / M$ & 10 years & $\begin{array}{l}\text { Paraganglioma } \\
\text { like }\end{array}$ & Dendritic cells & Dendritic cells & $\begin{array}{l}\text { No evidence of recurrence or } \\
\text { metastasis I year after surgery }\end{array}$ \\
\hline 7. & Ikeda T I998 [9] & $72 / F$ & 2 months & $\begin{array}{l}\text { Paraganglioma } \\
\text { like }\end{array}$ & $\begin{array}{l}\text { Sustentacular } \\
\text { cells }\end{array}$ & $\begin{array}{l}\text { Sustentacular } \\
\text { cells }\end{array}$ & Not mentioned \\
\hline 8. & Singh ZN I999 [10] & $55 / F$ & 4 months & Typical & -- & Diffuse & $\begin{array}{l}\text { Presented with LN metastasis; No } \\
\text { evidence of metastasis after I year }\end{array}$ \\
\hline 9. & De Lume MA 200I [II] & 20/M & 9 months & Classic & -- & Diffuse & Not mentioned \\
\hline 10. & Present case & $52 / F$ & 3 months & Classic & -- & Diffuse & $\begin{array}{l}24 \text { months, recurred thrice, } \\
\text { metastasis to skull bones and died }\end{array}$ \\
\hline
\end{tabular}

There was no family history of thyroid disease. She was a known hypertensive on treatment. On examination a $3 \times$ $2 \mathrm{~cm}$ lump was palpable in the lower part of neck, more so on the right side. This swelling moved with deglutition. No lymph nodes were palpable in the neck. No clinical evidence of abnormal parathyroid activity, Cushing syndrome, subcutaneous nodules or mucosal neuromas was present.

Computerized tomography (CT) scan neck showed a 3.5 $\times 2.5 \mathrm{~cm}$ hyper dense lesion in the right lobe of the thyroid without any associated lymphadenopathy. Fine needle aspiration cytology (FNAC) was suggestive of a poorly differentiated carcinoma. On laryngoscopic examination, bilateral vocal cords were mobile. Near total thyroidectomy was done without lymph node dissection. Postoperative period was uneventful. Unfortunately, serum calcitonin level was not estimated preoperatively but postoperative serum calcium and calcitonin levels were within normal limits. Thyroid weighed $24 \mathrm{gm}$ and thyroid capsule was intact. Cut surface showed a single nodule measuring $3.1 \times 2.2 \times 1.1 \mathrm{~cm}$ within the right lobe of thyroid. Nodule was partially encapsulated but well demarcated from adjacent normal appearing thyroid. Cut section of nodule was soft homogeneously black in color with grey white foci (Fig 1a). No satellite nodule was seen in the rest of the thyroid. Lymph nodes were not found in the specimen.

Tissue was fixed in 10\% neutral buffered formalin, routinely processed and paraffin embedded. Five micron thick sections were cut for hematoxylin and eosin staining and immunohistochemistry. Immunohistochemical staining was done by streptavidin-biotin peroxidase complex method and a panel of antibodies was used to char- acterize the tumor. These include thyroglobulin (dil 1:50), thyroid transcription factor (TTF, dil 1:100), synaptophysin (dil 1:50), carcinoembryonic antigen(CEA, dil 1:100), melan A(dil 1: 100), epithelial membrane antigen (EMA, dil 1:50), pancytokeratin (CK; dil 1:100), cytokeratin 19 (dil 1:100), S-100 protein (dil 1:100), vimentin (dil 1:100), chromogranin (dil 1:50), calcitonin (dil 1:50), HMB 45 (dil:100), p53 (dil 1:50), bcl-2 (dil 1:50)

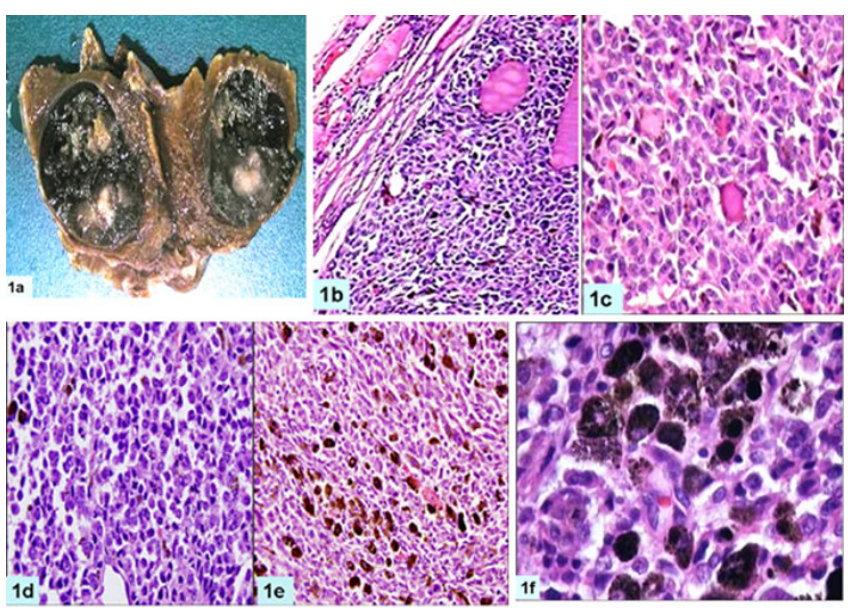

\section{Figure I}

Gross photograph showing cut surface of right lobe of thyroid demonstrating a well circumscribed black colored nodule, (Ia); photomicrograph shows encapsulated nodule compressing adjacent normal thyroid (Ib, H\&E, $\times 100)$; caught up normal thyroid follicles in the tumor (Ic, H\&E, $\times 200$ ); higher magnification demonstrating plasmacytoid appearance of tumor cells (Id, H\&E, $\times 200$ ); tumor cells containing brownish black pigment and focal areas of spindling (le, H\&E, $\times 200)$; high magnification shows tumor cells laden with melanin (If, H\&E, $\times 400$ ) 
and MIB-1 (dil 1:50). All antibodies were obtained from M/s Dako Patts, Denmark except p53 and TTF which were procured from M/s Novocastra UK and M/s Neomarker, USA respectively. High temperature antigen retrieval using microwave was carried out by immersing the sections in $10 \mathrm{mM}$ citrate buffer ( $\mathrm{pH} \mathrm{6.0)}$ ) and heating inside a 750 watt microwave oven in full power for 30 minutes except for chromogranin, HMB-45, S-100 and EMA.

MIB-LI was calculated as percentage positive nuclei in the highest labeled areas. For electron microscopy, the tissue was fixed in $2.5 \%$ glutaraldehyde, post-fixed with $1 \%$ osmic acid and embedded in epoxy resin. Routine thick sections were cut to select representative area for ultra-thin sectioning. Ultra-thin sections were double stained with uranyl acetate and lead citrate and examined under a transmission electron microscope (TEM, Morgagni 268, Holland). Microscopic examination showed a cellular tumor arranged in solid sheets, nests and trabecular pattern with few residual normal thyroid follicles (Fig 1b-f). Tumor cells were polygonal, round to oval, at places showing spindling. Cellular outlines were indistinct with moderate to abundant amphophilic cytoplasm. Nuclei were vesicular and showed moderate pleomorphism, multi-nucleation and conspicuous nucleoli. Frequent mitoses were present but necrosis was not seen. Scant perivascular eosinophilic amorphous material was present which was reactive to Congo red stain and showed apple green birefringence on polarization. Brown-black, coarse intracytoplasmic pigment was present in the tumor cells (Fig. 1e-f) which bleached with Masson-Fontana stain and it was negative for iron stain. Melanin was present in all types of tumor cells. Tumor cells showed diffuse immunopositivity for calcitonin, HMB-45, carcinoembryonic antigen, synaptophysin, chromogranin, vimentin and epithelial membrane antigen but focal paranuclear dot-like positivity for cytokeratin (Fig 2a-f), and were negative for thyroglobulin, S-100, melan-A and TTF (Table 2). Electron microscopy revealed abundant com- pound melanosomes, premelanosomes in various stages of melanogenesis and sparse membrane bound dense core neurosecretory granules measuring 50-200 nm along with intermediate filaments (Fig 3). Patient was discharged on fourth post operative day and was doing well.

Follow up: However in the follow up, she developed local recurrence twice after 10 months and 18 months of operation in the soft tissue of neck. Serum calcitonin levels were within normal range. Excision of recurrent nodules showed medullary carcinoma without pigment production. After 3 months of second recurrence, she developed multiple nodules at the same site and surgical excision was done in another hospital. After this surgery she had multiple metastases to the scalp and died after 24 months of first surgery. Mutational analysis for ret oncogene could not be done.

\section{Discussion}

Medullary carcinoma of thyroid (MTC) is a tumor of thyroid parafollicular $\mathrm{C}$ cells, which are derived from neural crest. MTC can mimic any tumor structurally and functionally and has also been described as solid carcinoma, hyaline carcinoma and C-cell carcinoma [1]. Classically tumor cells are round to polygonal with amphophilic granular cytoplasm and have medium sized nucleus. Tumor cells are spread in solid sheets separated by highly vascular stroma, hyalinised collagen and amyloid [11]. Unusual varieties of MTC described are melanin producing MTC [3-11], true papillary form [12], mucinous or amphicrine form [13], clear cell variant [14], small cell variant [15] and giant cell type [16].

Our patient was a 52-year-old lady with mass in the thyroid region in the neck for three months. Histopathologic examination showed features of medullary carcinoma with melanin production. Mitoses were frequent $(>10 /$ hpf) in some foci which is unusual for MTC. Multinucleated tumor giant cells were present. These giant cells had

Table 2: Summary and comparison of immunohisochemical profile of the previously reported cases

\begin{tabular}{|c|c|c|c|c|c|c|c|c|c|c|}
\hline $\mathrm{IHC}$ & Present case & $* 3$ & $* 4$ & $* 5$ & *6 & $* 7$ & $* 8$ & $* 9$ & $* 10$ & $* \|$ \\
\hline Calcitonin & + & + & + & + & + & + & + & + & + & + \\
\hline HMB-45/Melanin stain & + & + & + & + & + & + & + & - & + & + \\
\hline Carcinoembryonic antigen & + & & & & + & & & + & & \\
\hline Synaptophysin & + & & & & & & & & & \\
\hline Chromogranin & + & & & & + & & + & + & & + \\
\hline Epithelial membrane antigen & + & & & & & & & & & \\
\hline Vimentin & + & & & & & & & & & \\
\hline Cytokeratin & + & & & & & & & + & + & \\
\hline S- 100 & - & & & & - & & + & + & + & \\
\hline Melan-A & - & & & & & & & & & \\
\hline
\end{tabular}

*REFERENCE NUMBER

+- positive,

- - negative 

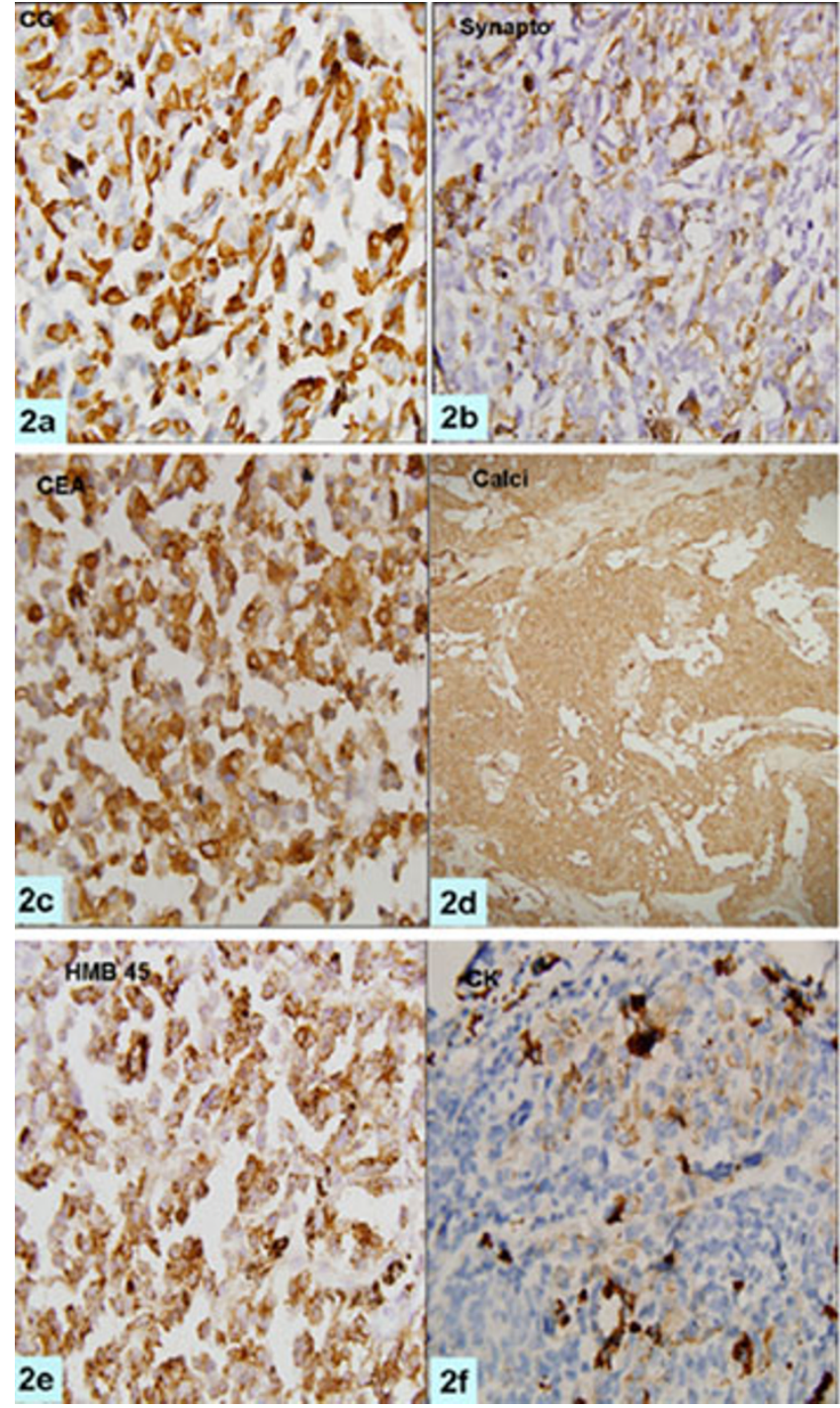

Figure 2

Photomicrographs showing tumor cells to be immunopositive for chromogranin A, synaptophysin, CEA, Calcitonin, HMB-45, and pan-CK (a-f, ×200 each).

hyper chromatic, pleomorphic nuclei with prominent amphophilic to eosinophilic nucleoli. Positivity for Fontana-Masson and negativity for iron stain confirmed pigment to be melanin. Tumor cells were positive for calcitonin which is the most specific marker for parafollicular cells [1] and proved beyond doubt that this was a melanin producing MTC and not a metastatic melanoma. Positive immunostaining for cytokeratin, chromogranin A, synaptophysin and carcinoembyonic antigen further buttressed above diagnosis. MTCs are generally negative for thyroglobulin as has been seen in the present case [17]. However mixed medullary carcinomas are known for thyroglobulin immunopositivity secondary to follicu-

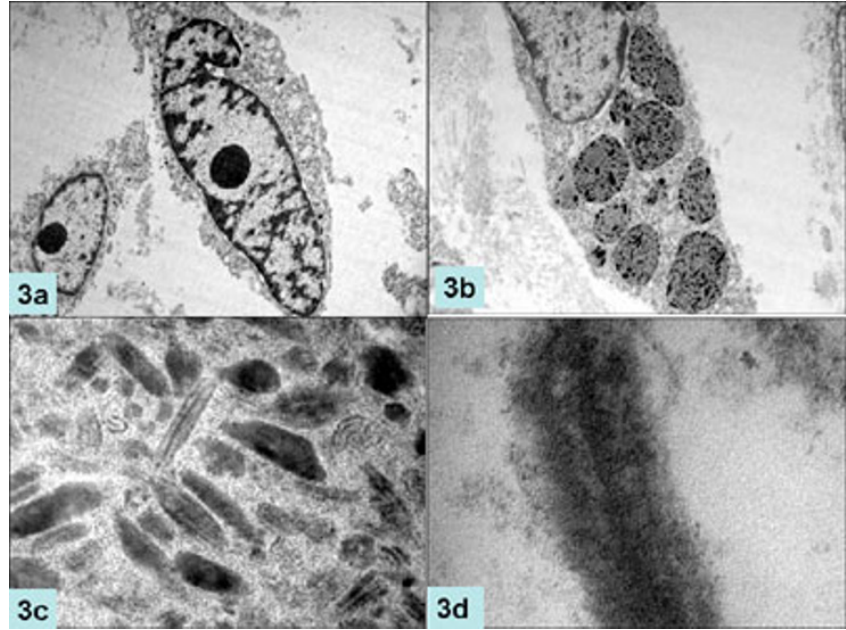

Figure 3

Electronmicrographs showing oval to spindle shaped cells with prominent nucleoli (a, $\times 2250$ original magnification) packed with compound melanosomes and premelanosomes (b, $\times 6250$ ); higher magnification of premelanosomes demonstrating internal structure $(c, \times 8250)$ and electron dense neurosecretory granules $(d, \times 6250)$.

lar differentiation. It has been hypothesized that mixed medullary carcinoma of the thyroid may be derived from common stem cells capable of differentiating into both follicular and parafollicular tumor cells [18]. Conversely, Volante et al [19] raised the possibility that trophic factors secreted by neoplastic and host cells might have a significant role in the tumorigenesis of mixed MTC. The demonstration of immunoreactive calcitonin within the neoplastic cells and the lack of thyroglobulin reactivity further support the diagnosis of a pure medullary carcinoma. Ultra structurally, tumor cells contained abundant melanosomes and premelanosomes but sparse neurosecretory dense core granules.

Black thyroid glands have been described in patients of cystic fibrosis, obstructive lung diseases and in patients who received minocycline for long duration. Pigmentation in these conditions is secondary to accumulation of lipofuscin. Presence of melanin in this case along with absence of clinical features ruled out these conditions. Metastatic melanoma has to be excluded before considering melanin producing medullary carcinoma as the primary diagnosis. Melanoma is the most common metastatic tumor in the thyroid $[20,21]$. Routine hematoxylin and eosin stain may not help much in differentiating melanoma from MTC with melanin production. In the present case the tumor cells showed pleomorphism with prominent nucleoli, foci of high mitotic counts and the melanin pigment. Features favoring MTC were organoid pattern; moderate to abundant eosinophilic cyto- 
plasm and scant amyloid like material, however melanoma can show these features [21]. The presence of amyloid material favors the possibility of former. Immunohistochemistry and ultra structural examination are essential tools in diagnosing MTC [11] and differentiating it from melanoma in difficult situations. Calcitonin is indispensable in these situations. Immunohistochemical expression of S- 100 protein and especially HMB- 45 by the pigmented tumor cells is further proof of melanocytic differentiation. All the previously reported cases showed calcitonin and HMB-45 expression in tumor cells. Ikeda et al did not find HMB-45 positivity in the sustentacular-like pigmented cells, possibly due to loss of antigenicity secondary to prebleaching. These cells were however, positive for S-100 stain. Marcus et al demonstrated presence of melanin and neurosecretory granules by Fontana-Masson and Gremalius argyrophil silver stain. Most of the cases showed chromogranin positivity to support for neuroendocrine differentiation. Electron microscopy showing the premelanosomes and neurosecretory granules within the same tumor cells clinches the diagnosis of MTC with melanin production $[3,4]$. Melanoma does not contain neurosecretory granules and intermediate filaments of the cytokeratin type [22].

Melanin producing medullary carcinoma thyroid was first described by Marcus et al in 1982 [3] and since then eight cases have been reported in the literature [3-11] including one case from our institute [10]. Salient features are summarized in Table 1. Age ranged from 20 to 72 years with equal male to female ratio. Duration of symptoms varied from 15 days to 14 years. None of them showed c-cell hyperplasia. Interestingly all the reported cases showed variable histomorphological features. In the case reported by Marcus et al there was evidence of only scanty melanin production which was localized to dendritic cells which did not have neurosecretory granules [3] Similarly the case reported by Ikeda et al [9] showed paraganglioma like picture and pigment was localized to the sustentacular cells. The possibility of paraganglioma was not considered in view of calcitonin expression in these cells. In later studies it has been shown that melanosomes and neurosecretory granules are present in the same tumor cells [5]. The case reported by Kimura et al [6] showed glandular differentiation and both types of cells were pigmented.

We tend to agree that tumor arises by polyclonal evolution of a common neoplastic precursor cell, able to produce both melanin and calcitonin. These cells are derived from neural crest which has melanocytic and c-cell characteristics within the same cells or show a mixed phenotypic expression. This is further supported that some of pigmented medullary carcinomas showed paraganglioma like morphology [9] which were derivatives of neural crest.
The prognosis of this variant is not exactly known, due to scarcity of cases. Of the nine previously published cases, follow up was mentioned in five patients only. Of these, two patients showed systemic metastases in the follow up and one had lymph node metastasis at the time of presentation. The case under discussion had very high mitotic count in some foci and had recurrence thrice in the soft tissue of neck and metastases to skull bones within 24 months of surgery. The high mitotic rate as seen in this case may be associated with poor prognosis. Whether the presence of melanin contribute to its aggressiveness remains to be elucidated. Therefore more cases of such type need to be documented in order to predict the exact behavior of this variant.

\section{Conclusion}

Melanocytic differentiation in medullary carcinoma of thyroid is very rare. The prognostic and therapeutic significance of this variant of MTC is not exactly known but this variant appears to be more aggressive; hence it needs to be documented in literature to know the exact behavior of this variant.

\section{Competing interests}

The author(s) declare that they have no competing interests.

\section{Authors' contributions}

KS, MCS and DJ are primarily responsible for drafting, literature search, and submission of the manuscript. RK supervised treatment. All authors have read and approved the final manuscript.

\section{Acknowledgements}

Written consent was obtained from the patient for publication of study.

We are grateful to Dr. Vikram Deshpande, Assistant Professor, Department of Pathology, Massachusetts General Hospital, Boston, USA for doing immunohistochemistry for calcitonin.

\section{References}

I. Hazard JB, Hawk WA, Crile G Jr: Medullary (solid) carcinoma of the thyroid; a clinicopathologic entity. J Clin Endocrinol Metabol 1959, 19:152-61.

2. Uribe M, Grimes M, Fenoglio-Preisser C, Feind C: Medullary carcinoma of the thyroid gland:clinical, pathological and immunohistochemical features with review of literature. Am J Surg Pathol 1985, 9:577-594.

3. Marcus JN, Dise CA, LiVolsi VA: Melanin production in a medullary thyroid carcinoma. Cancer 1982, 49:25 I8-26.

4. Posen JA, Adamthwaite DN, Greeff $\mathrm{H}$ : Melanin-producing medullary carcinoma of the thyroid gland. A case report. S Afr Med I 1984, 65:57-9.

5. Eng HL, Chen WJ: Melanin-producing medullary carcinoma of the thyroid gland. Arch Pathol Lab Med 1989, I I 3:377-80.

6. Kimura N, Ishioka K, Miura Y, Sasano N, Takaya K, Mouri T, Kimura T, Nakazato Y, Yamada R: Melanin-producing medullary thyroid carcinoma with glandular differentiation. Acta Cytol 1989, 33:6I-6.

7. Beerman H, Rigaud C, Bogomoletz WV, Hollander $H$, Veldhuizen RW: Melanin production in black medullary thyroid carcinoma (MTC). Histopathology 1990, 16:227-33. 
8. Ben Romdhane $K$, Khattech R, Ben omelanthman M, Gamoudi A, Ammar A, Cammoun M: Melanin production in medullary thyroid carcinoma. Histopathology 1995, 27:569-7I.

9. Ikeda T, Satoh M, Azuma K, Sawada N, Mori M: Medullary thyroid carcinoma with a paraganglioma-like pattern and melanin production: a case report with ultrastructural and immunohistochemical studies. Arch Pathol Lab Med I998, I 22:555-8.

10. Singh ZN, Ray R, Kumar N, Aron M, Gupta SD: Medullary thyroid carcinoma with melanin production - a case report. Indian J Pathol Microbiol 1999, 42:159-63.

II. de Lima MA, Dias Medeiros J, Rodrigues Da Cunha L, de Cassia Caldas Pessoa R, Silveira Tavares F, de Fatima Borges M, Marinho EO: Cytological aspects of melanotic variant of medullary thyroid carcinoma. Diagn Cytopathol 200I, 24:206-8.

12. Kakudo K, Miyauchi A, Takai SI, Kitamura H, Kuma K, Kumahara Y: C cell carcinoma of the thyroid. Papillary type. Acta Pathol JPN 1979, 29:653-659.

13. Golouh R, Us-Krasovec M, Auersperg M, Jancar J, Bondi A, Eusebi V: Amphicrine-composite calcitonin and mucin-producing carcinoma of the thyroid. Ultrastruct Pathol 1985, 8:197-206.

14. Landon G, Ordonez NG: Clear cell variant of medullary carcinoma of the thyroid. Hum Pathol 1985, 16:844-7.

15. Harach HR, Bergholm U: Small cell variant of medullary carcinoma of the thyroid with neuroblastoma-like features. Histopathology 1992, 21 1:378-80.

16. Kakudo K, Miyauchi A, Ogihara T, Takai SI, Kitamura H, Kosaki G Kumahara Y: Medullary carcinoma of the thyroid. Giant cell type. Arch Pathol Lab Med 1978, I 02:445-7.

17. de Micco C, Chapel F, Dor AM, Garcia S, Ruf J, Carayon P, Henry JF, Lebreuil G: Thyroglobulin in medullary thyroid carcinoma: immunohistochemical study with polyclonal and monoclonal antibodies. Hum Pathol 1993, 24:256-62.

18. Jiang C, Tan Y, Li E: Histopathological and immunohistochemical studies on medullary thyroid Carcinoma. Zhonghua Bing Li Xue Za Zhi 1996, 25:332-5.

19. Volante M, Papotti M, Roth J, Saremaslani P, Speel EJ, Lloyd RV, Carney JA, Heitz PU, Bussolati G, Komminoth P: Mixed medullary-follicular thyroid carcinoma. Molecular evidence for a dual origin of tumor components. Am J Pathol 1999, I 55:|499-509.

20. Shimaoka K, Sokal JE, Pickren JW: Metastatic neoplasms in the thyroid gland. Pathological and clinical findings. Cancer 1962, I 5:557-565.

21. Perry MD, Gore M, Seigler HF, Johnston WW: Fine needle aspiration biopsy of metastatic melanoma:a morphologic analysis of 174 cases. Acta Cytol 1986, 30:385-396.

22. Caselitz J, Janner M, Breitbart E, Weber K, Osborn M: Malignant melanomas contain only the vimentin type of intermediate filaments. Virchows Arch A Pathol Anat Histopathol 1983, 400:43-5I.

\section{Publish with Bio Med Central and every scientist can read your work free of charge}

"BioMed Central will be the most significant development for disseminating the results of biomedical research in our lifetime. "

Sir Paul Nurse, Cancer Research UK

Your research papers will be:

- available free of charge to the entire biomedical community

- peer reviewed and published immediately upon acceptance

- cited in PubMed and archived on PubMed Central

- yours - you keep the copyright
BioMedcentral 